\title{
Khazars or "Saltovo-Majaki Culture"? Prejudices about Archaeology and Ethnicity
}

\author{
Bozena Werbart
}

\begin{abstract}
This paper deals with the problems and discussions of the diversified cultural changes and the multicultural aspects of prehistoric societies. Prejudices about archaeology and "ethnicity" are exemplified by the almost 150 year old discussions on the Khazar khaganate, alternately a distinct delimited archaeological culture from the 8th-9th-centuries the Saltovo-Majaki culture. The interpretation of Khazarian material culture has often been made in terms of "ethnicity", and yet the cultural identity, the multiplicity of the society, etc., are not translated to the material culture. The economical, social and religious changes are the most significant phenomena within the "Saltovo-Majaki culture" and/or the Khazar khaganate: the transition from nomadism to sedentism, from tribal aristocracy to feudalism, and the transformation to a monotheistic religion. The common denominator for the Khazaria and the Saltovo-Majaki culture is, in my opinion, the pluralism of the social structures and economy, and the multidimensional character of cultural identity. The formation of complexes of archaeological items common to the whole of the steppe and forest/steppe areas, does not allow for connections between a specific archaeological material and a specific "ethnic" group of the past or of modern times.
\end{abstract}

Bozena Werbart, Institute of Archaeology, University of Lund, Sandgatan 1, S-223 50 Lund, Sweden.

"History does indeed serve present society, but serves it the better the more it seeks to understand the past on the past's own terms". A. Marwick. 1989. The Nature of History.

\section{THEORETICAL OUTLINES}

The intensive research into the interaction between different kinds of ethnic groups and different cultural manifestations has now been superseded by a tendency to look for diversified cultural changes, the multicultural and multiethnic aspects of prehistoric and historic societies. Ethnicity in archaeology can point to a number of different and simultaneous identities, group mentalities or societies.

The ethnocentric way of understanding ethnicity as a group subdivision, differentiation and demarcation line, which separates one's own cultural group from "others" - the archaeological concepts of culture - was used to describe ethnic groups on the basis of criteria such as customs, religion, language and origin. But no useful purpose is served by classifying ethnic groups in accordance with cultural characteristics. People and groups are able to move into and out of these ethnic categories without any change taking place (Svanberg \& Runblom 1991:75 ff.). It is even less appropriate to classify ethnic groups according to archaeological cultures. Taking the material remains of prehistoric societies as their point of departure, archaeologists have created artificial cultural concepts 
which have been associated, more often than not uncritically, with a clearly ethnic identity. The global way of understanding ethnicity aims at collective cultural identity, and at the same time continues to be a dynamic, social phenomenon, including social contacts and interactions between groups of people, of different genders and ages. Ethnicity need not, therefore, have anything to do with the traditional word "people".

Ethnicity in archaeological research in the former Soviet Union was associated with the problem of "ethnogenesis" and "ethnic indicators". Why was the problem of "ethnogenesis" so overdimensioned and why was it given so much attention? The reasons were ethnopolitical rather than academic. Ethnogenetic studies were prohibited in the Soviet Union during the early 1930s, when the internationalistic ideology predominated. Theories relating to migrations were rejec- ted, and it was claimed instead that each region reflects the history of individual people from the earliest periods to modern times. M. Chudjakov, for example, pointed out that the Volga Bulgars were not of Turkish origin but had developed locally, and M. Artamonov maintained that the Khazars did not arrive in the valley of the river Don from the eastern and northern Caucasus, but developed out of existing local groups (Chudjakov 1931; Artamonov 1949:4 f.; Bulkin \& Klejn \& Lebedev 1982:272; Shnirelman 1993:60 f.). Nevertheless, the situation was totally changed in the middle of the 1930s, when the national politics were reversed for the sake of Soviet (Russian) nationalism. The endless debates on the nature of archaeological cultures, on the homelands of various ethnic communities, and on the deepness of their roots in their modern territories have been characterized by prejudice (Shnirelman 1993:

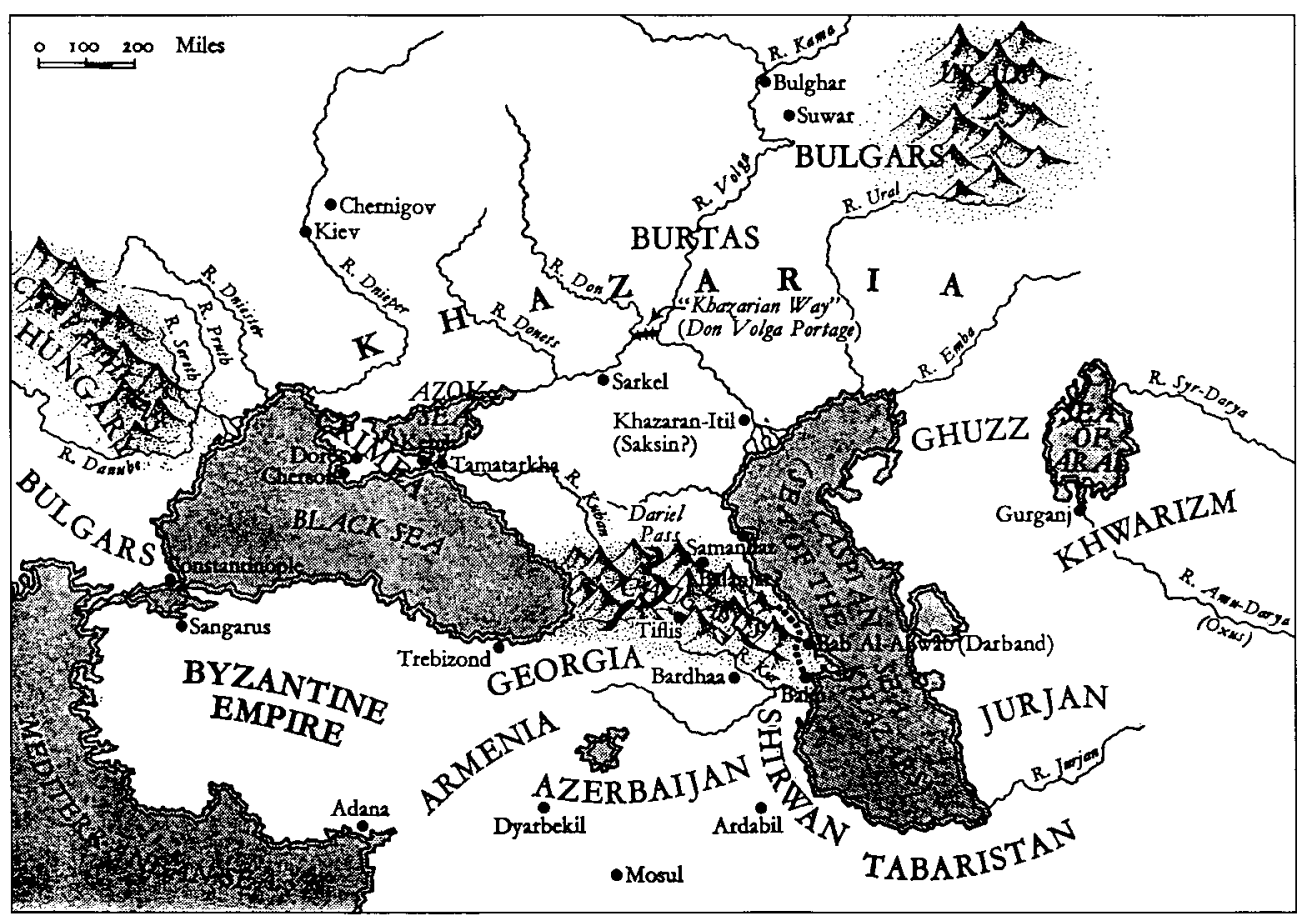

Fig. 1. The Khazar khaganate. (Distribution after Koestler 1967). 
68). Nationalism was the basis of this kind of research, and the crucial issue for the ethnogenetic discussion in the end of the 1930s was Slavic-Russian archaeology. The German "ethnogenetic expansion" gave rise to the Slavic "ethnogenetic expansion". These tendencies from the 1930s and 1940s played, I suppose, an important role in the formation of present, post-modernistic nationalistic movements in the former Soviet Union.

Prejudices about archaeology and ethnicity can be exemplified by the almost 150 year old discussion on the Khazaria (or Khazar Kingdom). During the last 40 years the names "Khazar Kingdom", "Khazar khaganate", and "Khazarian culture" were applied alternately to a distinct delimited archaeological culture from the 8th-9th centuries - the "Saltovo-Majaki culture" (Saltovo-Majackaja kultura). Two archaeological places gave their names to the Saltovo-Majaki culture, which was regarded by the Soviet scholars as a nomadic/semi-nomadic culture in the boundary zone between the forest and the steppe near the Don and the Azov Sea: the cemetery and the hillfort Verchneje Saltovo on the eastern bank of the river Donets, about $40 \mathrm{~km}$ east of Charkov in Ukraine, and the Majackoje gorodishche (Majaki hillfort) near the river Don (Pletnjeva 1967:3 ff.; Pletnjeva 1989: 4 f.)

From the 7 th to the 10th century, in the early European Middle Ages, the Khazars inhabited regions between the Black Sea and Caspian Sea, south of the Volga Bulgaria. The Khazarian khaganate was bounded in the west by Petjenegs, in the south by the Abbasidic Caliphate (see Fig. 1). During the 950s the Khazarian khaganate could no longer defend itself against the all too aggressive Russian Princes of Kiev. The great Khazar khaganate was annihilated in 965-66 AD by Svjatoslav Igorevich, Prince of Kiev, and his druzjina which harried likewise in the Volga Bulgaria, and which finally plundered the cities of Sarkel and Tmutarakan. After that Khazaria became a mysterious country (Boba 1967: 130; Gumiljev 1967; Wyszomirska 1989:143; Petrukhin 1995:485).

The complex relations between the distributions of material culture items and historically known groups, and the way in which ideas about the definition of these groups and the material culture associated with them have varied, are one of the most difficult points in the discussions about the Saltovo-Majaki culture and Khazaria. Important aims and questions can be crystallized: What do the concepts "Saltovo-Majaki culture" and "Khazars" mean? Who were the Khazars? What kind of correlations existed between these phenomena? Which chronological, chorological and archaeological aspects of the Saltovo-Majaki culture have been observed? Why were the Khazars associated with the Jewish religion?

\section{THE KHAZAR DEBATE}

Already during the 1850 s historians and numismatists began to be interested in the problem of Khazaria (Wyszomirska 1989: $135 \mathrm{ff}$.). The direction of the Khazar debate was not only of an archaeological but also of a historical, linguistic and numismatic character, as well as of a religio-historical character (Erman 1884; Zambaur 1902; 1911; Kmosko 1924; Anderson et al 1926; Kokovcov 1932; Togan Validi 1940; Arbman 1939,1942, 1955; Artamonov 1940, 1952, 1955, 1956, 1958, 1962; Boba 1967; Pletnjeva 1967; 1978; 1989; Bykov 1971; 1974; Minorsky 1978; Magomedov 1985; Petrukhin 1989; 1993; 1995 , among others).

The scholars were in disagreement about the very name "Khazar" (chazar, chasar, kasar); nevertheless many of them suggested that it does not mean any definite "people" and should not be associated with any locality, but with modus vivendi, the way of life (see Pelliot 1949:216; Minorsky 1978:124; Rolle 1981:413). The word "Khazar" can mean "a person without permanent residence", which can possibly be compared to 
the word "beduin". In the Islamic written sources (Hudud al'Alam, Mahmud al Kashgaris), "Khazars" refers to different tribes with different dialects (Rolle op.cit.), and in this way it emphasized the multiethnic and multireligious character of the Khazar state. The linguistic debate pointed out, morever, the multiplicity of the Khazarian kingdom and likewise its complexity, with different groups of people speaking different languages. The Khazarian language was spoken by only one group, and therefore it disappeared without any trace; the language of the Volga Bulgars was further preserved (see Minorsky 1987.124 f.).

The first selected publications about the Khazars, by D.M. Dunlop and A.N. Poliak, attracted attention by concentrating on the Jewish religion of the Khazar khaganate: The History of a Jewish Kingdom in Europe (Poliak 1951) and The History of the Jewish Khazars (Dunlop 1954). D.M. Dunlop emphasized the Khazars' very important place in history through their contacts with the Byzantine Empire. The greatest controversies arose with a book by Arthur Koestler, The Thirteenth Tribe. The Khazar Empire and its Heritage, published 1976 in London and in Swedish translation first 1992 (Koestler 1976; 1992). In the Khazar kingdom, Koestler wanted to see the origin of the eastern European Jewry. Nevertheless, all the historical and linguistical facts contradicted his theories. Today the majority of scholars consider that the Khazaric elements in the Jewish eastern European immigrations were of insignificant character, in spite of statements about the origin of eastern European Jewry in the Khazar khaganate. According to many researchers, to associate the Khazars with a modern eastern European Jewish population is an impossible and unnecessary task (Arbman 1955:49; Sharf 1971: 98 ff.; Minorsky 1978:143; Ludwig 1983:1787). In the beginning of the 10th century the first Jews came to Poland from Spain via Germany and Slovakia, and from Frankfurt, Wien and
Prague, where the early Jewish communities were already established. Another Jewish immigration came to Cracow from Kiev. According to Ibrahim ibn Jacob from Prague and Ibn Kordadbeh, these routes led from the West to the East rather than vice versa (see among others Balaban 1931). On the commercial route - Mainz, Prague, Cracow and Kiev - the Jewish tradespeople became well established in the large international trade in central Europe (Balaban 1931: 322 ff; Arbman 1955:49 f.).

The prejudices concerning the Khazar khaganate survived, nevertheless, to modern times. The comprehensive book by A. Koestler has caused much confusion in discussions on ethnic and religious issues. As was previously pointed out, the interpretation of ethnicity can always be used for other purposes, where changes are possible in the meaning and content (Werbart 1996). To uncritically interpret the book by A. Koestler can likewise lead to prejudicial statements, as for instance in R.P. Olofsson's discussion from 1994 in the Swedish newspaper "Dala-Demokraten", in an article entitled "A Jewish state on the Caspian Sea" (Olofsson 1994).

In a catalogue from the 1985 exhibition "The Caliphate and the Barbarian in the North", I. Jansson characterized the Khazar state as a "political dominance of a JewishTurkic tribe, which came, unbeknown when, to be converted to Judaism" (Jansson 1985: 58). But if we at all can "label" the "ethnic" terms in the debate on the "Khazars", then the Khazars were not "a Jewish-Turkic tribe", but rather a multiplicity of different societies and groups of people, with different religions but with a dominating state religion - Judaism (Wyszomirska 1989:135 ff.). The earliest religion of the Khazars was the shamanism of nomadic/semi-nomadic societies (Dunlop 1972:948). The most interesting Khazarian phenomenon for the linguists and religio-historians was the conversion to Judaism in, according to written sources, an 
evident period and not, as I. Jansson claimed, "unbeknown when" (Jansson 1985:58; Wyszomirska 1989:144). The conversion was carried out, according to Russian archaeologists, in the beginning of the 9th century or, more exactly, around 830 AD (Pletnjeva 1967; 1989), and according to A. Koestler in 740 A.D. (Koestler 1976). The prejudices about the Khazars became likewise noticeable among some Russian scholars. N. Gumiljev gives an account of an archaeological expedition in the delta of the river Volga, where he uses distinct delimited "ethnic" terms for particular finds and phenomena, for instance, "Khazar culture", "Turkic culture", "Khazar burials" and "Petjeneg burials". "The real Khazar nomads were the Turks, and the merchant urban population were the Jews", emphasized N. Gumiljev (1967:84), echoing a quite typical late medieval prejudice about the mercantile interests of the Jewish population. The confusion is total when he describes different types of objects, a confusion which has to do with a contamination of the concepts of archaeological cultures and "ethnicity": "burials" are often "Khazars" or "Petjenegs", while pottery is, on the contrary, "of the Saltovo type"; and he indicates strict distinct "ethnic" boundaries (Gumiljev 1962; 1967:74 f.). A much more diversified attitude to the archaeological and historical conceptions, and a quite different view of these issues, is represented by S.A. Pletnjeva and V.I. Petrukhin (Pletnjeva 1989; Petrukhin 1995).

If following the previous and also the current discussions about "Khazars", their role was either overdimensioned or neglected. The same is true about the role of Judaism in the Khazar khaganate.

Discussions about the ethnic and religious aspects have been "hot" in the archaeological literature and have often been prejudiced, particularly in the debate about the "Khazars" and/or Saltovo-Majaki culture. But etnhicity is a subjective and variable phenomenon, and for that reason we do not know what has been considered an ethnic term in the Khazaria, in Visigotic Spain, or in the Langobardic territory of southern Italy (see, among else, a discussion in Harrisson 1994:9 f.).

\section{KHAZARIA AND JUDAISM}

While discussing more or less scientific debates on the Khazars, two aspects may particularly be observed:

- that the "Khazars" were presumably a Turkish nomadic society, with Judaism as the official state religion since the beginning of the 9 th century ( $830 \mathrm{AD}$, see, among others, Pletnjeva 1967; 1989), and

- that the Khazarian state has consisted of a multiplicity of different ethnic groups and groups of languages (Slavonic, Turkic, Caucasian and Arabic populations) and, among others, of the Jewish societies which had been arriving here from the whole of the Caliphate, Byzantium and Spain.

In the big towns of Khazaria (Sarkel, Itil) the Jewish population composed, according to written sources, approximately $30 \%$ of the society, a minority among Muslims and Christians. During the end of the 9th century the "Khazarian" Judaism was spreading out to the Caucasus (the descriptions of the Spanish/Jewish culture in Byzantium in Benjamin of Tudela; Sharf 1971:98). The Jewish population came to Khazaria, escaping the persecution in Byzantium, on Crimea, and in the Caliphate, between the years 786 and $809 \mathrm{AD}$ (according to the Arabic historian Ali al-Mas'udi; Sharf 1971:98). The problems with the "Khazars" ethnicity" is very complex. Many scholars regarded the Khazars as a conglomerate of different societies of Altaic/Turkic and Alanic origin, perhaps with Hunnish elements; a sovereign mosaic of societies and a diversified union of different groups of people in the steppe and forest/steppe regions of southeastern Europe. The Khazars appear in the historical sources as contemplating themselves exactly as a conglomerate of groups of people re- 


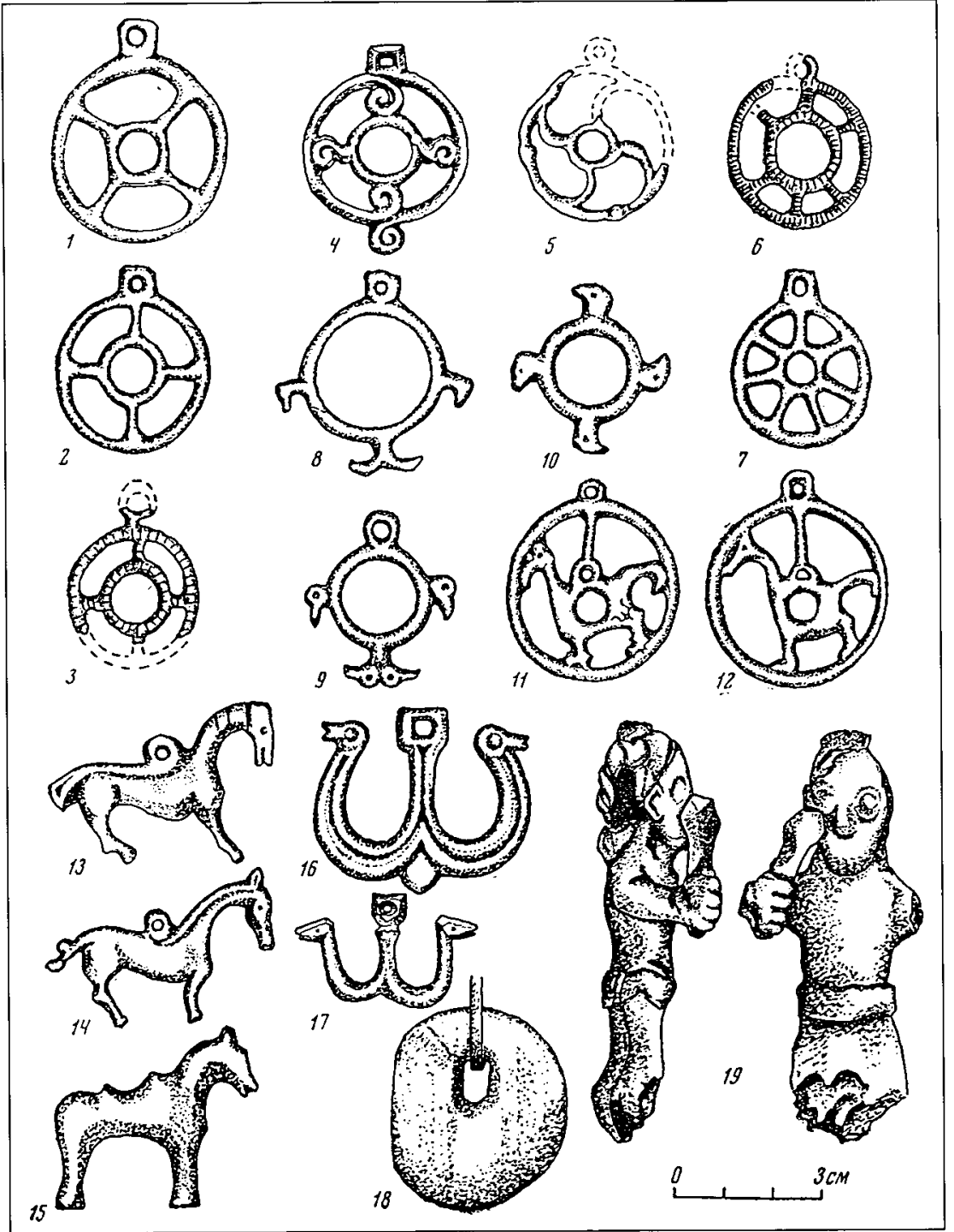

Fig. 2. Sun amulets from Verchneje Saltovo and Dmitrijevskij cemeteries. 19 bronze figurine from Sarkel (after Pletnjeva 1967).

lated to the Avars, Ugrers, Onogurs, Volga Bulgars and Savirs - among other places in the letters between the Khazar king Joseph and Hasdai ibn Shaprut, a Jewish physicist and minister to the caliph Abd al Rahman III from Cordoba. The so-called Khazarian correspondence has been frequently discussed by different scholars (Wyszomirska 1989:145).
Judaism was presumably practiced already in the middle of the 8 th century, at the latest around $800 \mathrm{AD}$, by King Obadja (approx. 799-809) as an official religion in the Khazar state - a modified version of the Jewish religion. In some measure it was a question of introducing a monotheistic religion, unifying the multiplicity of different societies. Owing to the practice of Judaism in 
the Khazaria, the majority of the population, according to Pletnjeva (1967:171), were able to write. The first mention of the Jewish religion in the Khazar khaganate is in Latin, and can be dated to the year 866 (Szyszman 1957:174; Artamonov 1962:471; Barthold et al. 1978:1175; Wyszomirska 1989:144 f.).

Already during the 7 th century a Khazar kingdom had been created, which was of considerable importance for the commercial connections between the North and South, and between the East and West. In addition to the Turkic, Arabic and Jewish societies, the Khazaria was inhabited by the Petjenegs, Radimitjs, Vjatitjs, Poljans, Volga Bulgars, and by a whole line of different Caucasian and Caspian tribes (Lowmianski 1957:151; Artamonov 1962:114ff.; Pletnjeva 1967; 1978; 1989; Magomedov 1975:275 ff.; Barthold et al. 1978).

The Arabic, Byzantine and Hebraic written historical sources bring into focus the religious tolerance and the trinity of the Khazar khaganate: the Jewish, the Muslim, and the early medieval Christian faith, where a religious multiplicity and tolerance seems to be a self-evident issue. In the Khazar towns, the churches, synagogues and mosques composed a characteristic picture. A religious tolerance, without parallel in history, as well as a certain religious syncretism has been the matter of course. The religious syncretism or indifference is often manifest in the nomadic societies around the Black Sea (Minorsky 1978:122; Wyszomirska 1989: 146). The religious part of the population of the Khazar khaganate was living in the big towns; the steppes were inhabited by the secular and shamanistic groups. The religious beliefs in the different societies at the Don, which were included in the Khazar khaganate, reveal a great deal of information. Different types of amulets, mostly sun amulets, and anthropomorphic bronze figural sculptures are widely dispersed within the Khazar khaganate, among other places in the graves in Saltovo and Dmitrijevskij, Fig 2.
According to Turkic tradition, the sun amulets are interpreted as a symbol of the god of heaven, Thengri-khan. The so-called white Khazars formed their nomadic settlements in a ring: the cult of the sun (Pletnjeva 1967: 179). Some time after the $830 \mathrm{~s}$, after the introduction of Judaism, the amulets disappear from the settlements and cemeteries.

During the 8 th century, the new social and economic conditions called for a state and homogeneous religion. That the Khazars "chose" the third religion, Judaism (after a disputation in the presence of the Khazar king Joseph), meant, according to Artamonov (1962), an independent position between two parties - Christianity and Islam; Byzantium and the Caliphate. The choice of the Khazars was well thought-out and diplomatic: they rejected neither Christianity nor Islam, but proceeded the third way - a political action of high dignity (Wyszomirska 1989: 146).

Judaism, as a state religion, played in the Khazaria a role of political independence and equality with both the Byzantine Empire and the Caliphate. The Khazars precluded, in that way, every form of dependence in relation to the Caliphate or Byzantium. Moreover, the Khazars emphasized Judaism's place as a third world-religion (Artamonov 1962:264 f.).

The Khazar kingdom (khaganate) during the end of the 9th century and the beginning of the 10th was a polyethnic and multireligious state. The khaganate was a political/ economic organization with a so-called double kingdom (khagan, a term known since $652 \mathrm{AD}$ : the great king and the representative king), a Eurasian sacred kingdom (Ibn Fadlan's description of history; Frazer 1917; Czegledy 1966:16). The Khazarian tradition of two kings relates to the ancient social practice and is reflected in the mytho-epic motif of the murder of the sacral king, as on the Khazarian silver scoop from Kotskij Gorodok on the $\mathrm{Ob}$ river or on the mountings from two drinking-horns (Fig. 3) found 
in the great mound in Chernaja Mogila at Chernigov, north of Kiev (Laszlo 1972:103; 1974; Petrukhin 1995:475 ff; 482:fig. 3). The decoration depicts the Khazarian epic motif of the defeat of the khagan in his fight with a rival, the depiction of Svjatoslav's victory over the Khazarian khaganate 965-66. According to V.J. Petrukhin, the grave reflects, however, "the polyethnic composition of the princely milieu - Slavic, Scandinavian and Turkic" (Petrukhin 1995:475). That signifies the importance of the Khazars in the creation of the Kievan state. During the 9th century, the title of khagan was likewise used in the Russian Kiev, as an indication of the competition for power against the Khazarian khagans; among others, Svjatoslav's son and his grandson - Vladimir and Jaroslav the Wisebore the title of khagan (Novoseltsev 1982; Petrukhin 1995:485).

\section{THE KHAZAR KINGDOM OR}

SALTOVO-MAJAKI CULTURE?

Cultural concepts are being questioned at present time within both archaeology and social anthropology (Ekholm Friedman et al.; Werbart 1994a). The traces of material cultures that are studied by archaeologists are not simply concrete examples of material remains, but also symbolize age, gender, ethnicity and perhaps other phenomena too.

Artifacts are regarded as being of little or no use as indicators of ethnicity in archaeology; nevertheless, artifacts are perceived as metaphors of human history and human memory. Polish archaeologists in the 1950s1970 s had a tendency to favour Slavic "artifacts", for example, and they neglected those of Germanic provenance - as a direct show of opposition to the German archaeology of the 1930s (Gruszecki 1993:17).

The history of archaeology reveals that artifacts have at times been hidden in the "backyards" of repositories, unmentioned or overlooked (Werbart 1996).

The previous Soviet struggle against "cosmopolitism" has likewise been reflected in the archaeological research, among

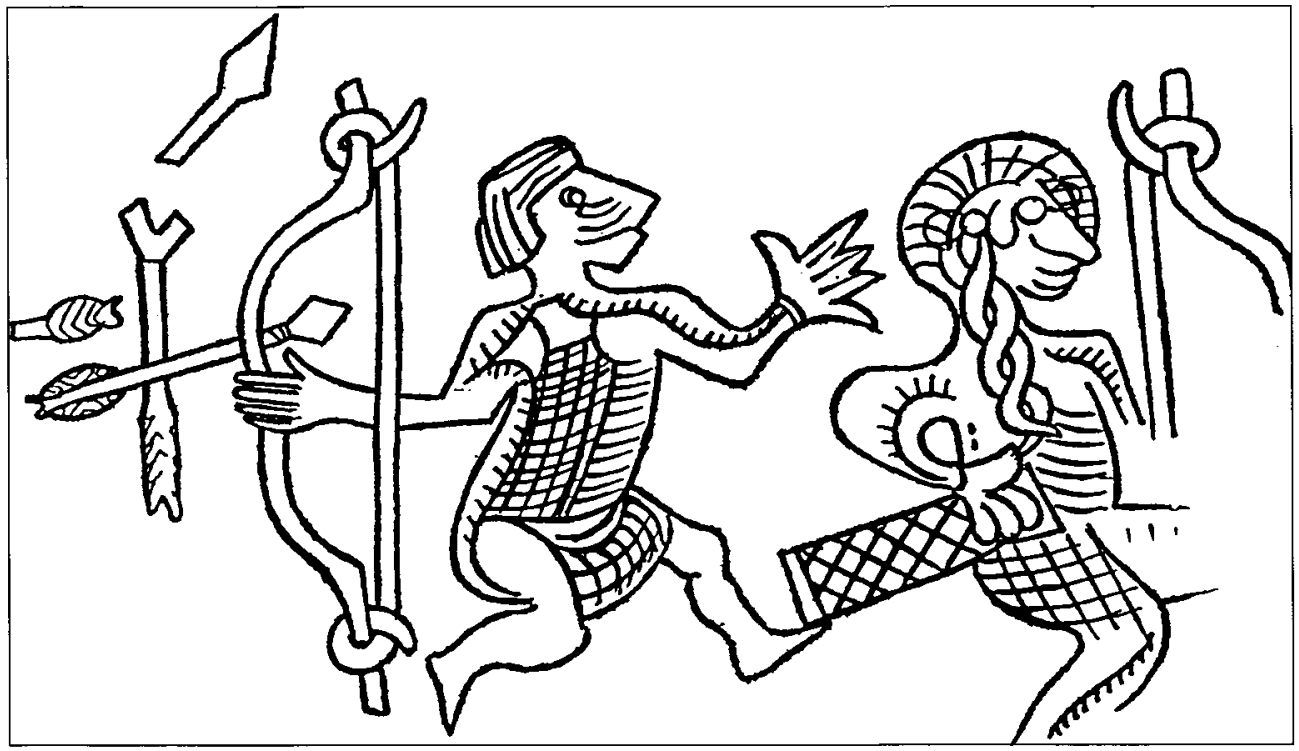

Fig. 3. Detail of decoration on the mounting of rython from Chernaja Mogila (Laszlo1972). 
other things in the views on the "Varjags" and "Khazars"(see i.a. Petrukhin 1993). Some of the Soviet archaeologists called the remains of the Khazarian material culture the "Saltovo-Majaki culture", others called them the "Khazarian culture". Some of the archaeologists of the 1950s, for instance B.A. Rybakov, "degraded" the role of the Varjags from the position of the founders of Rus' to participants in an "adventurous gang", "Normans", which, during a very short time, inhabited Kiev (Petrukhin op cit).

The role of the Khazars was in the same way either overdimensioned or "degraded". Various kinds of maps were, for instance, presented with extreme differences in the territorial delimitations. B.A. Rybakov identifies a small Khazarian territory between the Volga and Don, with the cities of Sarkel and Itil. According to M.I. Artamonov, B.A. Rybakov reduced the importance of the Khazarian state (Rybakov 1953:128 ff.; Artamonov 1962:459). S.P. Tolstov overdimensioned, on the contrary, the significance of the Khazar khaganate, and located it to the Caspian Sea and in the Khorezm. The caravans and the so-called king route from Khorezm to the Volga, as well as the archaeological finds, indicated, according to Tolstov, a great Khorezm-Khazar state during the 10th and the beginning of the 11 th century (Tolstov 1948: 195; 1953). Nevertheless, no evidence existed of the connections between the Khazar khaganate and Khorezm. Already in the end of the 19th century, about ten archaeological sites of the Saltovo-Majaki culture were known from the right bank of the river Don. Some of the 19th-century Russian scholars associated these sites with the Alan cemeteries in the northern Caucasus (Spicyn 1909; Pletnjeva 1967:3). The important result of M.I. Artamonov from 1962 was the theory that the 8 th9th-century societies at Don and on the Azov Sea, a conglomerate of different groups, had been included in the Khazar multicultural state, and that the economical, administra- tive, and political changes can be traced from the nomadic life to the agricultural settlements, as well as the rise of handicrafts and trade and the progress of the cities (Artamonov 1962; Pletnjeva 1967:4 ff.)

The political and intellectual context of the concept of archaeological "culture" was often interpreted with its link with cultural ("ethnic") identity. When history and prehistory are used for confirmatory purposes, and when the politicians refer to them as witnesses of the truth, there is good reason to be on one's guard. "Almost all people have their own Kosovo, and if they are looking for it, all people of the world should be able to indicate, with support from the historical sources, that they are victims of historical injustice“, emphasized T.H. Eriksen (1995). A frightening example of the success of anti-democratic tendencies was the political tumult at the WAC-3 (World Archaeological Congress) in New Delhi in 1994. There were to be no discussions nor resolutions at meetings of the executive committee on the Ayodhya issue. Neither S. Colley (1995) nor others called this problem by its right name: that it was a totalitarian, Stalinistic and antidemocratic way to stop the debate - an unprecedented case at international meetings (Shennan 1994:7; Colley 1995; Eriksen 1995).

The tragic consequence of intolerance is also the political misuse of archaeology. M.I. Artamonov, the excavator of Sarkel and a scientist and archaeologist, called the finds from Sarkel "Khazarian" and depicted, moreover, the Khazar khaganate, which played a fundamental role in the creation of the Russian Kiev, as well as the dominating religion, Judaism. In the beginning of the 1950s, during the Stalinistic period, it roused the irritation of other scholars, particularly Artamonov's interpretation of the markings on the bricks (Artamonov 1962:303; Wyszomirska 1989: 138, fig. 2). He was criticized officially in "Pravda" by Ivanov with support from B. Rybakov, who called all finds from Sarkel a "Saltovo-Majaki culture" with Slavonic, not 
"Khazarian", roots. Rybakov meant that Artamonov idealized the Khazar state, which is a sign of "a bourgeois attack against Russians", and that he was well-deserved of criticism in "Pravda". M.I. Artamonov was forced to be self-critical in his articles, but he was "rehabilitated" later in the 1960s, since in 1962 he published a new book "Istorija Chazar". He associated here Sarkel (19491951 years' excavations), Cimljanskoje gorodishche and the Saltovo-Majaki culture with the Khazars (Ivanov 1951:3; Artamonov 1952:42 ff; 1962).

M.I. Artamonov emphasized the progressive role which the Khazars played in the history of Europe. The Caucasus constituted a distinct boundary zone between Europe and the Caliphate. Caliph al-Mandjur (754-775 AD) had the best relations with the Khazar khaganate. The importance of the Khazars as defenders of eastern Europe against the conquests of the Caliphate, is undoubtable; they opened likewise the door to the Byzantine culture (Artamonov 1962: 457; Barthold et al. 1978). The cultural historical importance of the Khazars in the links between eastern Europe and the Islamic world, and the international trade between the 8th and 10th centuries, is quite comprehensive. The route of the transit trade via Khazaria, from the 9th century to the $960 \mathrm{~s}$, was covered by Islamic dirhams, which had an enormous importance for the delivery of coins and silver to eastern and northern Europe (Bykov 1971:33).

In spite of the customs tariff, which was claimed by the Khazar khaganate, the Scandinavian trading travellers considered that it was worth coming to the region of the Caspian Sea. During the 9th century they received information about the Khazar khaganate. The Scandinavian tradesmen and tradeswomen came to establish valuable contacts along the river Volga, in the region of the Volga Bulgars, as well as in the towns of Itil and Sarkel, where they met commercial and business travellers from all over the world. These peoples' commmercial activity established a link between Asia and Europe (Arne 1914:299 ff.; Lowmianski 1957:119; Foote et al 1974:227). However, it is, perhaps, possible that the Khazarian traders had visited Scandinavia during the 9th-10th centuries.

Different opinions are prevalent about the connecting of the Khazar khaganate with the Saltovo-Majaki culture, even among present-day scholars. The hillfort of Verchnee Saltovo, the unfortified village, as well as the cemetery belong, according to I. Jansson, to the same culture, the "Saltovo culture", which is known from the territories at the Donets, Don and the Azov Sea, and likewise from the northern slopes of the Causcaus and from the middle Volga and Kama - consequently "from a considerable part of the Khazar state" (Jansson 1985:180). I.I. Ljapushkin emphasized in 1958, in his depiction of objects of precious metal from the cemetery at Saltovo and of bricks from Cimljanskoje gorodishche, that different opinions exist about Khazaria contra the Saltovo-Majaki culture (Ljapushkin 1958:139 ff.). He criticized M.I. Artamonov for the statement that no other culture than the Saltovo-Majaki culture is known in Khazaria during the 9th century. However, Ljapushkin believed that the Saltovo-Majaki culture was not a nomadic culture, and therefore had no connections with the Khazar khaganate (Ljapushkin op.cit).

Nevertheless, the multicultural and multireligious state based its economy on more complex grounds (see the current Russian literature - Pletnjeva and Petrukhin). According to ethnographers, no nomadic cultures were "absolutely" nomadic; a certain degree of agriculture has always been included (Pletnjeva 1967:8). Most of the scholars agreed that the Saltovo-Majaki culture coincided with the Khazar khaganate, and that the boundaries are identical. The archaeological boundaries of this phenomenon consisted of ca. 300 sites at the Donets, Volga and eastern Crimea (Fig. 4), with the characteristic build- 
ings in the fortification constructed of white mortar in Sarkel, Verchneje Tchirjurtovskoje gorodishche near Sulak in northern Dagestan, but also in Semender, Balandjar and Semikarakovskoje gorodishche, among other places (Pletnjeva 1967:44; Rolle 1981:417; Ludwig 1983:1788).

Discussion on the "ethnic origin" and "ethnogenesis" of the Saltovo-Majaki culture was a crucial issue for the Russian archaeologists: S.A. Pletnjeva has associated this culture with the Khazars (Volga-Khazars), other archaeologists with the Bulgarian tribes; only a few scholars regarded this culture in the same way as the Khazar state, as an "ethnic", multicultural conglomerate (Rolle 1981:418). S.A. Pletnjeva proclaimed in her book from 1967, Ot kochevij $k$ gorodam. Saltovo-Majackaja kultura (Pletnjeva 1967), that she is of the same opinion as Artamonov (1962) concerning the Khazar khaganate and the Saltovo-Majaki culture: namely, that there existed correlations and connections between these two phenomena. She emphasized also that her view is opposite that of Rybakov, and that the theories of Tolstov about Khazaria can mostly be regarded as products of the imagination. When studying

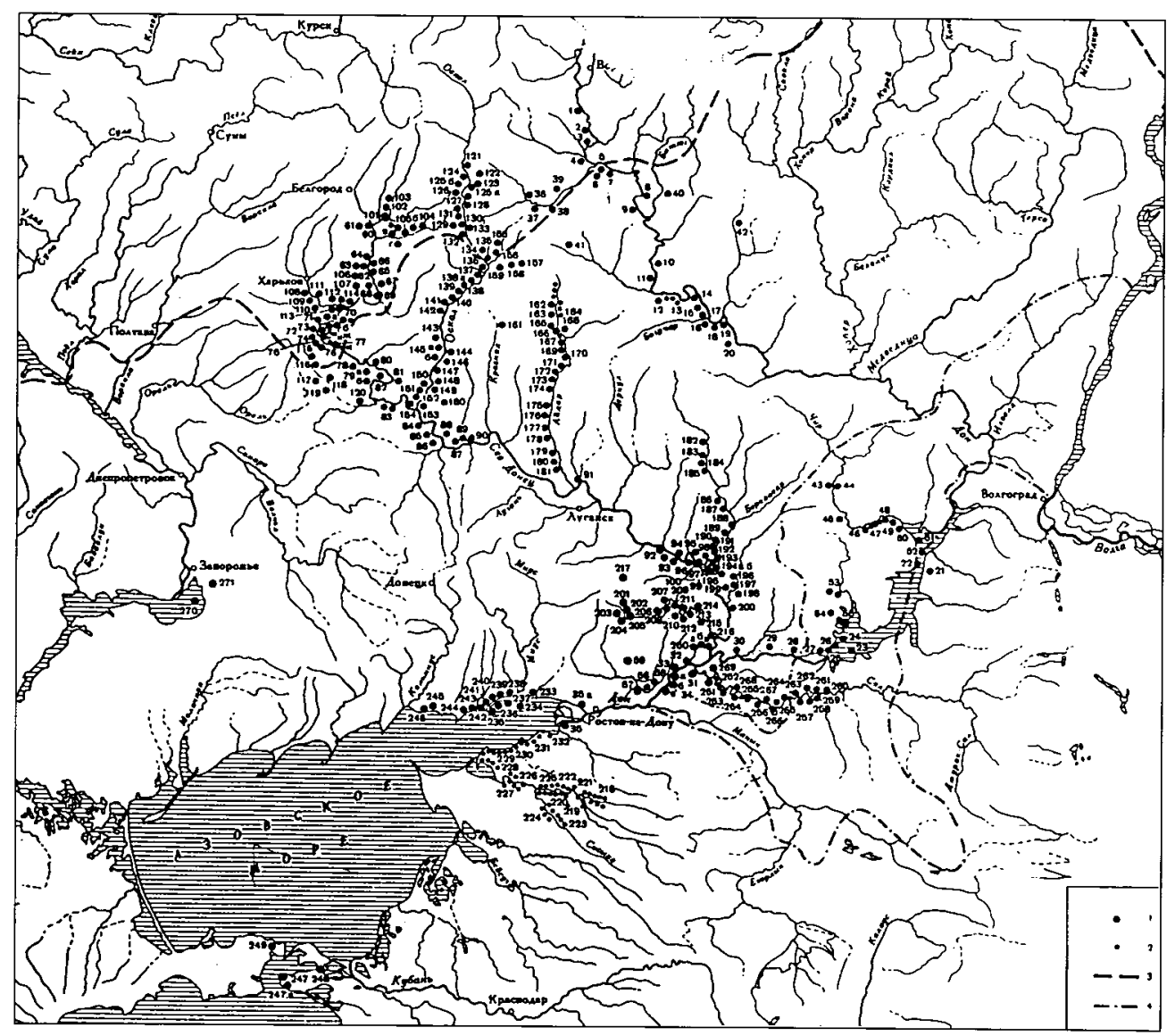

Fig. 4. Sites of the Saltovo-Majaki culture: cemeteries, settlements, gorodishcha, towns (after Pletnjeva 1967). 
references in Pletnjeva's book, the change of attitude after the end of the 1960s can be noticed; it is distinctly that M.I. Artamonov has been censored until the beginning of the 1960s (Pletnjeva 1967). In 1978 a new book by S.A. Pletnjeva was published in German: Die Chazaren. In 1989 Pletnjeva published Na slaviansko-chazarskim pogranichje. Dmitrijevskij archeologicheskij kompleks, 20 years after her first monograph. The part that treats the history of research in her book is comprehensive: she accounts for the 1962 publication Istorija Chazar by Artamonov, and the three volumes on the so-called Volga-Don archaeological expeditions from the years 1958, 1959 and 1963 (Pletnjeva 1989:3).

The Saltovo-Majaki culture with its regional variations was a culture included in the large state unit - the Khazar khaganate according to Pletnjeva (1989), and the Saltovo-Majaki culture was identical with the "culture of Khazar khaganate". The capital of Itil (Atil) was located in the delta of the river Volga; it is still not identified, and it was divided into three different units (alMasudi in the "Golden Roads", as well as depictions by Ibn Fadlan, Muruj al-Dhahab and ibn Rustah; Arbman 1962:117; Artamonov 1962:385 ff.; Barthold et al. 1978:1173). According to the written sources, Itil was a large town, presumably of the same character as Sarkel, a centre for the Khazarian transit trade from the 9th century to the $960 \mathrm{~s}$. The royal palace (castle of the khagan), on an island in the Volga, was built of white bricks, and composed part of the picture of the town. According to written sources, in this metropolis market places and public baths, bazaars, churches and synagogues, and schools and mosques existed. M.I. Artamonov located Itil approximately $144 \mathrm{~km}$ north of Astrakhan, and L.N. Gumiljev investigated this site in 1959; however, he did not find any traces of Itil (Artamonov 1962; Gumiljev 1967:61 ff.). It is not impossible that the remains of the city are lying below sea level. The archaeological excavations on the presumed site of Itil demonstrated that the right bank of the river Volga consists of the out-washed, alluvial layers (Gumiljev op cit). Gumiljev's work was a typical example of the afore-mentioned "ethnogenetic" studies in the former Soviet Union, particularly his distinct "ethnic" delimitations (Gumiljev 1967:84).

The border fortress and town Sarkel has been investigated at the lower Don; Sarkel could be defended not only from the broad side of the river, but likewise from the outside of the thick walls. The location near the important trade route between Itil and the region of the river Don, additionally emphasized the significance of the town. The Don was not an important sailing route during the 9th century. Sarkel has not, therefore, been built at the river, but at the country road, in order to increase the status of the Khazars in their western and north-western territories. According to the Byzantine written sources, the building of Sarkel was started ca. $834 \mathrm{AD}$, by request of a Khazar khagan (Artamonov 1955:118). The excavations of Sarkel demonstrated that this fortress was an architectonic masterpiece: a rectangular fortification with the earthworks, thick walls, resting on no foundation, with four towers, two gates, and a citadel, and built of sun-dried bricks and joined by a white limestone - the so-called White Town. Some part of the marble columns and capitals, like those from Cimljanskoje gorodishche, was of Byzantine quality (Artmanonov 1955: 105; 1958:9).

An approximately one-meter-thick culture layer, with Khazarian finds, covered the chronological period from the 840 s to 965 AD. According to Pletnjeva, in this so-called Khazar layer about 100 house constructions were investigated. Different types of cultural manifestations have been demonstrated in this area of excavation, and the finds seem to indicate the multiplicity and variation, as well as the trade connections not only with Crimea and Byzantium but also with central 


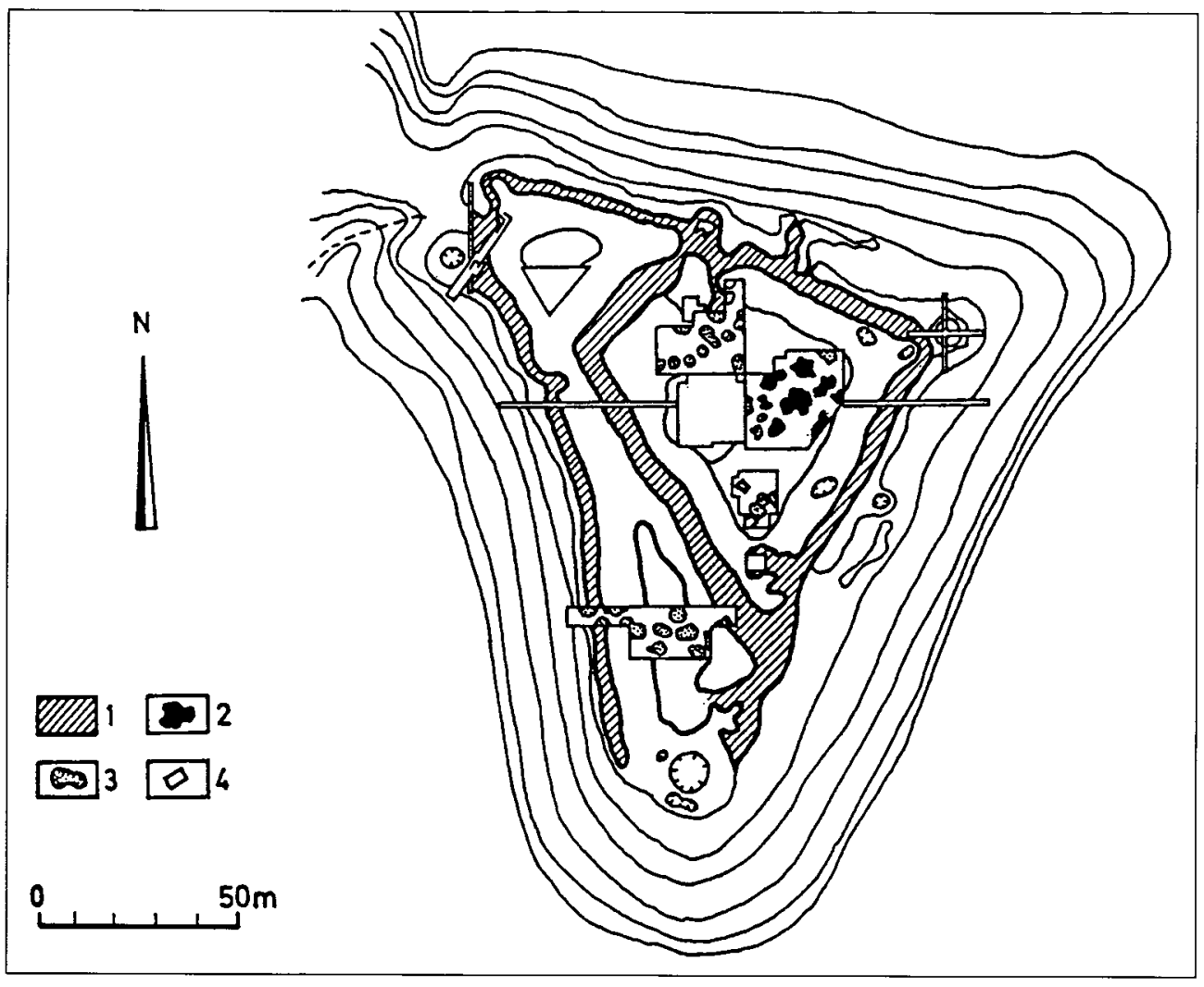

Fig. 5. Cimljanskoje gorodishche at Don (Rolle 198I).

Asia and the territories east of the Caucasus: glazed pottery, coins, and objects of art (Pletnjeva 1967:45 ff.). Many scholars suggested that on account of the character of the settlements, pottery, and buildings, a three-part division of the population is conceivable: the Muslim, the Christian, and the Jewish - a multiethnic and multireligious society (Artamonov 1962; Rolle 1981; Pletnjeva 1989). The dimensions of the bricks from Sarkel are not of Byzantine measures; they are both thicker and smaller. A similar technique is also known from Cimljanskoje gorodishche, where, besides the town architecture, the round nomadic yurts occurred, Fig.5. The figures on the bricks consist of schematic zoomorphic and anthropomorphic pictures, letters, and symbolic signs, which have been interpreted differently: as Hebrew letters, as old Turkic runes, or as symbols of the Jewish menorah (Artamonov 1962:388; Wyszomirska 1989:137, fig. 2). A ritual structure, very close to the wall of the fortress in Sarkel, contained a human skeleton with finds of both henna and a piece of paper by the hand bones, indicating contacts with central Asia (Samarkand, China?). This piece of paper was produced from a local material, but according to Chinese prescription (Artamonov 1958:54). After the destruction of Sarkel in 965, a new Russian town was built on its ruins, Belaja Vezja, which existed until 
the 12th century (Artamonov 1955:118). The Khazar settlements on Crimea are well known, among others those of Tmutarakan (Hermonassa), Phanagoreia, Pantikhapaion, and Myrmekion (Rolle 1981:420). One hundred $\mathrm{km}$ south of Sarkel another town is known, Semikarakovskoje, of the same character as Sarkel (Pletnjeva 1967:47 ff.).

Except for the, in most cases, suspicious and controversial written sources, the archaeological remains are numerous and comprehensive. The "Khazar" archaeology, or the archaeology of the Saltovo-Majaki culture, is based on the finds (jewellery, ornaments, belt mounts, pottery, bricks, mirrors, weaponry, and saddles, among other things), the architecture (from the palaces to the yurts), and the coins: Ard-al-Khazar dirhams (see, among others, Bykov 1974; Rispling 1987; Wyszomirska 1989:138 ff).

\section{MATERIAL CULTURE, KHAZARIA AND SALTOVO-MAJAKI}

The material culture indicated that the people constantly renewed and improved their knowledge. Therefore the material culture can contribute to a continuous redefining of the "ethnicity" (Fitzpatrick 1993:241).

The interpretations of Khazarian material culture, coinage and "art" have often been made in terms of "ethnicity", making a distinction between different types of material culture and "peoples" (Veit 1994; Fitzpatrick 1993:240). However, the cultural identity, the multiplicity of the society, the "ethnic" heterogeneity, and the cultural influences are, in most cases, not translated to the material culture, to the objects or grave forms.

In spite of many claims to the contrary, no object is "ethnospecific" as such! Different types of jewellery, mounts, belts, etc., can, perhaps, demonstrate the change of fashion, but not the ethnic differentiations. Many central and eastern European medieval archaeologists not only like to connect certain objects with archaeological "cultures", but also like to interpret them as "ethnospecific" (Bálint 1994:192).

C. Bálint, in his discussion about the Avars, Khazars, and the Slavic finds in Hungary, Bulgaria, and the rest of southeastern Europe, emphasized that it is not possible to, for instance, talk about "pan-Slavonic" types of objects as "ethnospecific", such as S-ended temple rings. This kind of find occurs in a gigantic area within the central European territory. In order to characterize, for instance, the Avars' archaeological cultures, several elements must be considered, such as Byzantine influences, and comparisons with the Khazars' material must be made (Bálint op cit.). The Avars' and the Khazars' graves are not, for instance, so very different. The burials with horses constitute rather an expression of the social phenomenon, without any "ethnic" contents. Both the late Avarian and Khazarian states were constructions of an oriental nature, with the political and territorial structures of a complex and multiplex character. The "slavophile, pan-Slavic period" after World War II, with an overemphasis on the Slavic elements and a close connection between archaeology and nationalism, was not only significant for the Soviet or Polish researchers; it was likewise visible in Hungary (Bálint 1994:191).

To bring more clarity to the problem of the material culture of the Saltovo-Majaki, S.A. Pletnjeva, in her monograph from 1989 about the complex of Dmitrijevskij, propagates for the publication of the entire material from this culture, which is, since the $1950 \mathrm{~s}$, still obscured, or hidden in the repositories! The archaeological material from Sarkel-Belaja Vezja is since the 1960s deposited in the Eremitage, and still not published after the excavations of 1949-1951 (Pletnjeva 1989:5). In the historical museum in Astrakhan only one small exhibition case with some archaeological finds is dedicated to the Khazars; the Jewish religion of the state is not mentioned. The new excavations of the Soviet/Bulgarian/Hungarian expedi- 
tion on the classical site of Majackoje gorodishche, during the years 1975-1982, as well as the new investigations of Verchneje Saltovo, are likewise still not published (Pletnjeva 1989:5). In the archaeological museum in Kiev two "Khazarian" exhibition cases contained, among other things, the gold jewellery, ornaments, and mounts from two Ukrainian kurgans, excavated 1961 in Glodosy, Kirovogradskaja obl. (Smilenko 1965), and 1927 in Gladkovka, Cherssonskaja obl. (the last one, not published, according to information from B. Hårdh). The twenty years of investigations in Dagestan was published in the 1980s (Baranov 1981; Magomedov 1985). The complex of Dmitrijevskij, about $50 \mathrm{~km}$ from Verchneje Saltovo, is located, according to Pletnjeva, in the boundary zone between forest and steppe, and is included in the complex of gorodishcha - about ten "White Stone fortresses" (castles). In this complex and on the sites at the Donets, the skeleton burials occurred inside the big "Saltovo" vessels (Pletnjeva 1989). The Dmitrijevskije gorodishche has been interpreted as a winter settlement for semi-nomadic feudal authorities; in the same way as Itil has been interpreted as a winter palace for the Khazar khagan. The settlement patterns and the habitation structures of the "Saltovo-Majaki" are richly varied: a lot of small settlements with houses with post constructions, pit-features, features and constructions with animal offerings, pottery workshops; the large settlements; gorodishcha with earthwork; gorodishcha with stone walls; the large towns and metropolises (Pletnjeva 1989:24 ff).

Pottery from the Saltovo-Majaki sites is very diversified. Pottery with linear ornamentation, geometrical patterns, and stamps at the rims, is characteristic of the forest/ steppe variant of the Saltovo-Majaki culture. This pottery appeared in the 8th-9th-century cultural layers in the large towns in the south - Sarkel, Tamatarka, Fanagoria, and Justanovskoje gorodishche (Afanasjev 1987:96 ff.; Pletnjeva 1967: fig. 28; Pletnjeva 1989:19).
Most striking about the 8th-9th-century pottery from these regions, is the multiplicity of different forms and ornamentation patterns: there is hand-made pottery, kitchen pottery, packing groups, jars, jugs, amphore and pithoi, as well as service vessels with clear influences from the late Roman/Byzantine pottery, turned on a hand-driven wheel and often with markings on the bottom. The grave pottery from the catacomb graves is also of variable forms (Pletnjeva 1967:102 ff.), Fig. 6 . The markings on the pottery and bricks were particularly comprehensive in the material from Sarkel. A.M. Shcherbak wanted, in these finds, to see three different cultural traditions: the Black Sea culture (Byzantine), the culture from Dnepr, and the nomadic culture. Some of the markings were associated with the Greek towns on the Black Sea, and with the Rus' Kiev (Shcherbak 1959: $362 \mathrm{ff}$.). The pottery from Sarkel indicates, nevertheless, the trade connections with central Asia, Byzantium and Trans-Caucasus.

Among the imported pottery found in Birka, the "Khazar" pottery is noticeable: a fragment of a jug of well-burnt ware (Bäck 1995:14, fig. 4).

The burial rituals in the Khazar khaganate indicate moreover different types of cultural manifestations at the Don and Donets. Various types of graves are known: catacomb graves, burials in pits, graves with horses, horse burials, double graves (often pair burials with a woman and a man), collective burials, and sometimes cenotaphs and memorial monument-cemeteries in Verchneje Saltovo, Dmitrijevo (with 152 catacomb graves), Verchnij Tchirjurt in Dagestan, and Aghach-Kala in the northern Caucasus (Smirnov 1951; Pletnjeva 1967:71 f.; Pletnjeva 1989:68 ff.). Cremation graves without mounds are also known (Rolle 1981: 420 ). In these various types of graves there occurred anthropomorphic bronze amulets, gilt bronze ornaments, buttons, toilet-sets, applications, silver jewellery, belt mounts and buckles (Fig. 7), weapons (iron swords, 


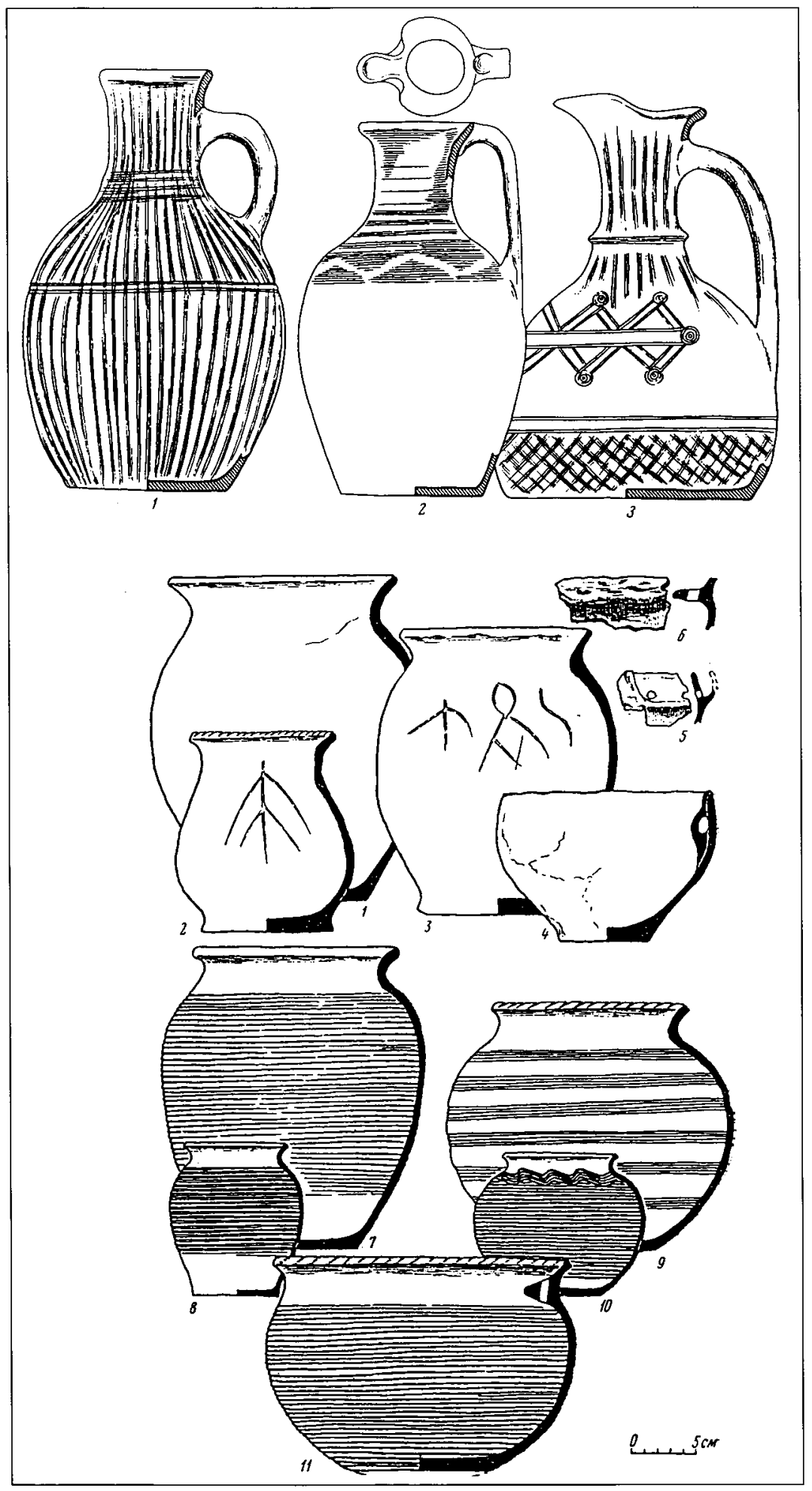

Fig. 6. Variation of pottery from the Saltovo-Majaki culture (Pletnjeva 1967). 
arrowheads, bows, saddles, lances and axes, leather helmets) as well as bracelets, rings, and beads of glass, stone and mosaic, Abbasidic silver coins, and vessels and mirrors, often richly decorated (Pletnjeva 1989:73 ff; fig. 51 ff; Wyszomirska 1989:143).

A completely equipped equestrian was, for instance, depicted on part of a saddle of bone from Dagestan (Magomedov 1975: 279). According to written sources, the dead Khazar kings were buried in the rivers, presumably a common tradition among the northern nomads; moreover, music was played at the Khazarian burials (Blake et al. 1949:34 ff; Smirnov 1951).

The belt mounts with stylized plant ornamentation, as well as the "heart-shaped" silver amulets with a loop and plant decoration and often with animal and human figures, have been interpreted by S.A. Pletnjeva as "Khazarian" or Saltovo-Majaki (Pletnjeva 1967). This kind of silver ornament and the belt mounts from the 9th-10th centuries, found in Birka as well as in the silver hoards from middle Sweden, Gotland and Scania, were usually called "oriental". H. Arbman interpreted these finds as "Khazarian" (Arbman 1940: tab 95 f.; 1942:303 ff.; 1955:142 f.; Hårdh 1976:49ff.; Jansson 1978:383 ff.; 1985; 1986). This type of ornamentation and jewellery is, however, known from the whole of the large southeastern European steppe area, and outside the boundaries of the Khazar khaganate, see Fig. 7.

Both the pottery and the other finds, such as jewellery, amulets, mounts, etc., can not only be attributed to the "Khazarian culture" or "Saltovo-Majaki culture"; they are not "ethnospecific", because the great diversity in form and decoration indicates rather the multiplicity of different influences from various territories - both from the Khazar towns, the Caucasus, the Black Sea, Byzantium, Crimea, the steppes in the East, and the region of Kiev. The "Saltovo-Majaki" culture is not homogeneous; it presents the same type of pluralism as all the "archaeological cultures“.

A unitary, official religion is not unique to the Khazar khaganate: in Volga Bulgaria, Islam predominated; in Donau-Bulgaria, Christianity. The religious tolerance in the Khazar khaganate constituted, however, a consolidated factor in the social and political life of the state. The importance of the dominating religion, Judaism, as a unifying political/social link in the multireligious and multiethnic state, is evident.

\section{CONCLUSIONS}

Consequently, what do the concepts "Saltovo-Majaki culture" and "Khazars" mean?

Discussions on the "ethnic affiliation" of the Saltovo-Majaki culture pointed out a variation of opinions. When studying the part that treats the history of research in the monograph by S.A. Pletnjeva (1967), it can be noted that some scholars (above all Soviet and Russian, but also Hungarian) regarded these societies as Khazarian, others as "Alanic", and still others as "proto-Bulgarian" or as "Magyars". "Slavic"("pan-Slavic") theories about the Saltovo-Majaki culture have also been presented (Pletnjeva 1967:7).

The "ethnogenetic studies" and the wellpublished discussions on the "origin" and "ethnogenesis" were fruitless, and, on account of their starting-points, they were judged to be a fiasco (see Werbart 1994b).

M.I. Artamonov was, perhaps, the first (1962) to emphasize that the Saltovo-Majaki culture means not only the "Khazars" but moreover a multiplicity of different societies, and that the Saltovo-Majaki culture has, at the same time, been included in the Khazar khaganate (Pletnjeva 1967:6 f.). S.A. Pletnjeva's most significant discussion on the Saltovo-Majaki culture maintained that this culture was not homogeneous (op.cit.). But is not multiplicity something which actually characterizes all "archaeological cultures"?

Ethnicity is, as mentioned before, a variable, multilateral, subjective phenomenon, and we don't know, therefore, what has been con- 
sidered as an "ethnic" term in Khazaria. An themselves as different from other people "ethnic group" consists of peoples who see (Horowitz 1985). The "ethnic group" has, in
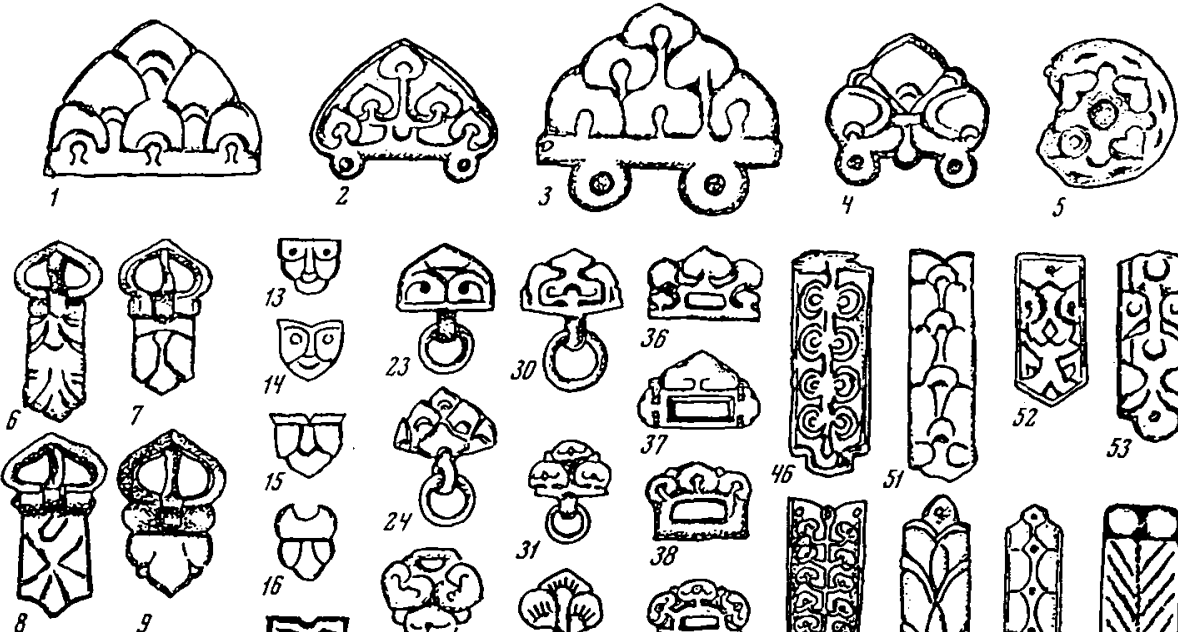

की

(2)
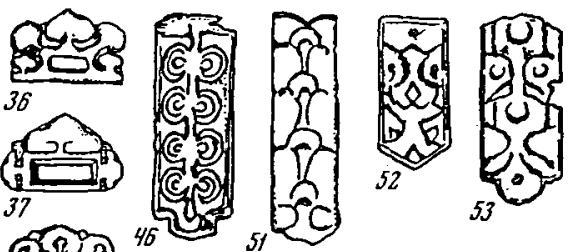

ए人

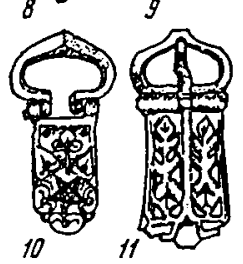

पु

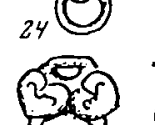

跑

25

(3) Prifin

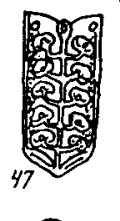

(O) 32

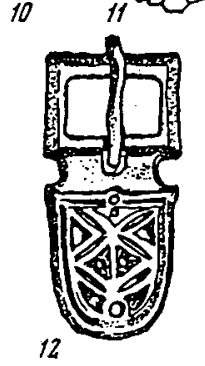

裂

(1)

SOS

हैم

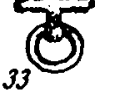

39

An

5

姃

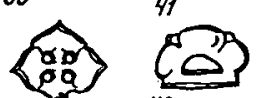

83

27

sab

42

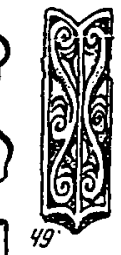

${ }_{54} \mathrm{P}$

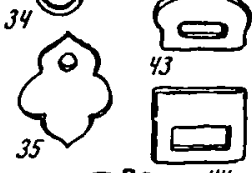

13

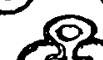

12
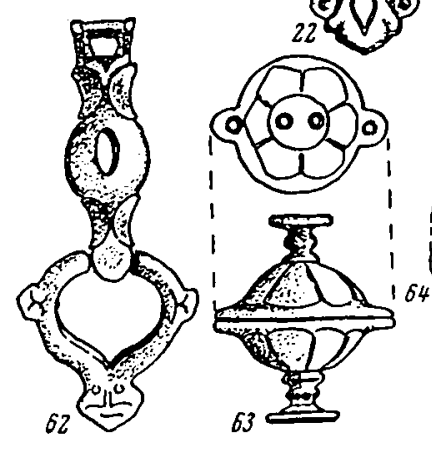

3
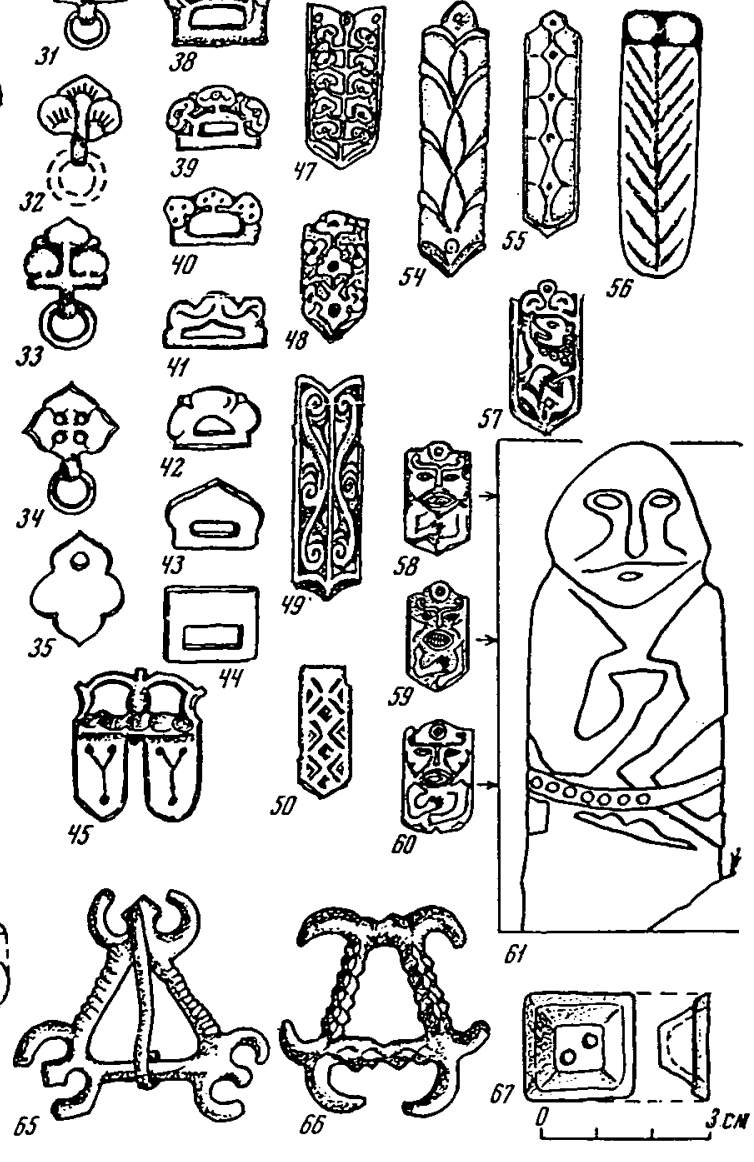

Fig. 7. Ornaments and mounts from Verchneje Saltovo; bronze and silver (Pletnjeva 1967). 
other words, been used in a very general way; for social groups of various constructions and in different parts of the world (Ekholm Friedman et al 1994:3).

The economical, social and religious changes are, perhaps, the most significant phenomena within the "Saltovo-Majaki culture" and/or the Khazar khaganate: the transition from an archaic economic formation, from nomadism and semi-nomadism, to sedentism; the transformation of the tribal aristocracy to a hierarchic feudalism; and the transition to a monotheistic religion. Even though some part of the population between the river Don and the Black Sea, had been living in the towns and castle structures ( $\mathrm{go}$ rodishcha), a large percent led a nomadic life, and they gradually changed their life and economy from tabor (camp-) nomadism to a semi-nomadic and sedentary economy (Pletnjeva 1967:179 f.). A unique form of double power (double kingdom) distinguished this specific political/economical organization - the khaganate.

The two hundred year old history of the Khazar khaganate came to an end, when the state was conquered in the $960 \mathrm{~s}$, and the traces of these diversified societies, cultures and religions disappeared. Khazaria was during the 8 th-10th centuries a powerful state, which stood out against much stronger kingdoms the Byzantine Empire and the Arabic Caliphate.

The large, archaeologically identified, cultural mosaic existed until the end of the 8th century within the enormous steppe territories between the Don and the Caucasus, with different nomadic societies which were later included in the Khazar union. From the end of the 8th until the 10th century the large, multiplex "nomad pot" was transformed into a more homogeneous picture of the state and cultures. The multitude of finds, the transition and prosperity of the economy, handicrafts, art, architecture, coinage, and the knowledge of writing, all indicated pluralism, influences, and contacts across large areas; in other words, that which archaeologists alternately called the "Saltovo-Majaki culture" or the Khazar khaganate. However, as S.A. Pletnjeva (1967:185) emphasized, we do know that the boundaries of the SaltovoMajaki culture are synonymous and parallel to the boundaries of the Khazar khaganate. S.A. Pletnjeva and other Russian archaeologists distinguished five variants of the Saltovo-Majaki culture in southeastern Europe, which are all "equal to" the Khazar khaganate: the archaeological finds of the Saltovo-Majaki type from the Don, the Azov Sea, Dagestan, Crimea, the lower Dnepr, and northwestern Bulgaria, among other places (Pletnjeva 1967:187, fig. 50). However, as was mentioned before, the spread of the Khazar state has been discussed in different ways by various scholars. S.A. Pletnjeva has mostly focused on the Dagestan variant of the Saltovo-Majaki culture around the Khazar khaganate. B.A. Rybakov and M.I. Artamonov pointed out the boundaries of the Khazar khaganate in quite different ways: according to B.A. Rybakov, the finds from the Saltovo-Majaki culture can not be regarded as "Khazarian" (Rybakov 1953). M.I. Artamonov, on the contrary, emphasized that the territory of the Khazar khaganate, according to archaeological sources, corresponded with the distribution of different variants of the Saltovo-Majaki culture (Artamonov 1962: 424). S.A. Pletnjeva stressed that she totally agrees with M.I. Artamonov (Pletnjeva op cit).

These distinctly different positions indicate the contamination and conglomeration of various problems and questions: What is archaeology? What is "ethnicity"? The only common denominator for the Khazarian khaganate on the one hand, and the SaltovoMajaki culture on the other, is, in my opinion, the pluralism of the social structures and economy, the multiethnicity and multireligiousity.

The high mobility of the populations in the large territories, the multidimensional 
character of its cognitions of cultural ("ethnic") identity, the mixed and complicated territorial and cultural groups and societies, and the formation of complexes of archaeological items common to the whole of the steppe and forest/steppe areas, do not allow connections between a specific archaeological material and a speciefic "ethnic" group of the past or of modern times.

Nowadays, it is more often the social anthropologists rather than the archaeologists who emphasize that identity is a life choice. People select and formulate their cultural identity and affiliation for themselves, including in the ethnic sense. In many mixed cultures, and even in the prehistoric multicultural societies, identity problems were always a sign of dualism. Ethnicity is difficult to study in the archaeological material and I am rather inclined to support an approach to understanding ethnicity (cultural identity) in archaeology as a social, variable and dynamic phenomenon, which includes social and cultural interrelations.

\section{English revised by Laura Wrang.}

\section{REFERENCES}

Afanasjev, G.E. 1987. Naselenje lesostepnoj zony bassejna Srednego Dona v VIII-X vv. (alanskij variant saltovo-majackoj kultury). $A O N$. Vyp. 2.

Anderson, W. \& Vasmer, R. 1926. Der Chalifenmünzfund von Kochtel. Dorpat.

Arbman, H. 1939. Birka. Sveriges äldsta handelsstad. Från forntid och medeltid. I. Stockholm.

- 1940-1943. Birka. Untersuchungen und Studien. I. Die Gräber. Text und Tafeln. KVHAA. Stockholm.

- 1942. Einige orientalische Gegenstände in der Birkafunden. Acta Archaeologica XIII:303315. København.

- 1955. Svear i Österviking. Stockholm.

- 1962. Vikingarna. Härnadståg. Handelsvägar. Kultur. Stockholm.

Arne, T. J. 1914. La Suéde et l'Orient. Archives d'Études Orientales $8^{\circ}$ vol 8 . Uppsala.

Artamonov, M. I. 1940. Sarkel i nekotoryje drugije ukreplenija v severo-zapadnoj Khazarii. Sovetskaja Archeologija VI. Moskva.

- 1949. K voprosu ob etnogeneze v sovetskoj archeologii. Kratkije Soobshchenija Instituta istorii materialnoj kultury 29. Moskva.

- 1952. Belaja Vezja. Sovetskaja Archeologija XV: 42-76. Moskva.

- 1955. Khazar-festningen Sarkel. Viking XIX:99120. Oslo.

- 1956. Khazarskaja krepost Sarkel. Acta Archaeologica Hungarica 7:321-341. Budapest.
- 1958. Sarkel-Belaja Vezja. Trudy Volgo-Donskoj Archeologicheskoj Ekspedicji I. Materialy $i$ Issledovanija 62. Moskva-Leningrad.

- 1962. Istorija Khazar. Leningrad.

Balaban, M. 1931. Kiedy i skad przybyli Zydzi do Polski? Historja i literatura zydowska ze szczególnym uwzglednieniem Zydów w Polsce vol II:322-325. Lwów-Warszawa-Kraków.

Bálint, C. 1994. Some ethnospecific features in Central and Eastern European archaeology during the early Middle Ages: the case of Avars and Hungarians. In: S.J. Shennan (ed.) Archaeological Approaches to Cultural Identity. One World Archaeology 10. London-New York.

Baranov, I. A. 1981. Nekotoryje itogi izuchenija turko-bulgarskich pamiatnikov Krima. Sofia.

Barthold, W. \& Golden, P. B. 1978. Khazar. The Encyclopedia of Islam vol IV:1172-1181. Leiden-London.

Blake, R. P. \& Frye, R. N. 1949. Notes on the Risala of Ibn Fadlan. Byzantina Metabyzantina. A Journal of Byzantine and Modern Greek Studies vol I, p II:7-37. New York.

Boba, I. 1967. Nomads, Northmen and Slavs. Eastern Europe in the ninth century. SlavioOrientalia II. Wiesbaden.

Bulkin, V.A. \& Klejn, L.S. \& Lebedev, G.S. 1982. Attainments and problems of Soviet archaeology. World Archaeology 13.

Bykov, A. A. 1971. O khazarskom chekane VIII- 
IX v.v. Trudy Gossudarstvennogo Ermitazja XII:26-36. Leningrad.

- 1974. Iz istorii denezjnogo obrashchenija Khazarii. Vostochnyje istochniki po istorii narodov jugo-vostochnoj i centralnoj Evropy vol III:26-71. Moskva.

Bäck, M. 1995. Importkeramiken i Birka. META. Medeltidsarkeologisk Tidskrift. 95:1. Lund.

Chudjakov, M.G. 1931. Finskaja ekspansja v archeologicheskoj nauke. Izvestija Gossudarstvennoj Akademii istorii materialnoj kultury 11-12. Moskva.

Colley, S. 1995. What happened at WAC-3? Antiquity 69 , No 262. Oxford.

Czeglédy, K. 1966. Das sakrale Königtum bei den Steppenvölkern. Numen. International Review for the History of Religions 13. Leiden.

Dunlop, D. M. 1954. The History of the Jewish Khazars. Princeton, New Jersey.

- 1972. Khazars. Sarkel. Atil (Itil). In: Encyclopedia Judaica 1971-1972:881-882. Jerusalem.

Ekholm Friedman, K., Alsmark, G. \& Johansson, R. 1994. Etnicitet och nationalism. Kulturell identitet $i$ historisk-antropologisk belysning. Unpublished paper, University of Lund.

Eriksen, T. H. 1995. Offer för missbruk av historien. Svenska Dagbladet 950105. Stockholm.

Erman, A. 1884. Die im Jahre 1882 vom Köngl. Münzkabinet erworbenen orientalischen Münzen. Zeitschrift für Numismatik vol XI: 64-70.

Fitzpatrick, A. P. 1993. Ethnicity and Exchange: Germans, Celts and Romans in the Late Iron Age. In: C. Scarre \& F. Healy (eds.) Trade and Exchange in Prehistoric Europe. Oxbow.

Foote, P. \& Wilson, D. M. 1974. The Viking Achievement. London.

Frazer, Sir J. 1917. The Killing of the Khazar Kings. Folklore. A Quarterly Review of Myth, Tradition, Institution and Custom (382-407). London.

Gruszecki, A. 1993. Cultural and national idenity and the protection of foreign fortifications in Poland. Problems of Heritage and Cultural Idenity in Poland:45-49. Warsaw.

Gumiljev, L. N. 1962. Khazarskoje pogrebenje i miesto, gdie stojal Itil. Soobshchenija Gossudarstvennogo Ermitazja 22. Leningrad.

- 1966. Otkrytje Khazarii. Istoriko-geograficheskij etjud. Moskva.

- 1967. New data on the history of the Khazars.
Acta Archaeologica Academiae Scientiarum Hungaricae 19:61-103. Budapest.

Harrisson, D. 1994. Etnicitet i historisk forskning: även ett tidigmedeltida problem. META. Medeltidsarkeologisk Tidskrift 94:3-4. Lund.

Haussig, H.W. 1981. Der Seidenhandel über die Chazaren mit Byzanz und Skandinavien. Les Pays du Nord et Byzance. Acta Universitatis Uppsaliensis. Figura, Nova Series 19:187193. Uppsala.

Horowitz, D. 1985. Ethnic groups in conflicts. Berkeley.

Hårdh, B. 1976a. Wikingerzeitliche Depotfunde aus Südschweden. Katalog und Tafeln. Acta Archaeologica Lundensia 4:9. Lund.

- 1976b. Wikingerzeitliche Depotfunde aus Südschweden. Probleme und Analysen. Acta Archaeologica Lundensia 8:6. Lund.

Ichenskaja, O. V. 1982. Osebonnosti pogrebalnogo obrjada i datirovka nekotorych uchastkov Saltovskogo mogilnika. Materialy po chronologii archeologicheskich pamiatnikov Ukrainy. Kiev.

Ivanov, P. 1951. Ob odnoj oshibochnoj koncepcji. Pravda 25 dec. 1951, No 359. Moskva.

Jansson, I. 1978. Ett rembeslag av orientalisk typ funnet på Island. Vikingatidens orientaliska bälten och deras eurasiska sammanhang. Tor 17. 1975-1977:383-420. Uppsala.

- 1985. Kalifatet och barbarerna i norr. Islam. Konst och kultur. Utställningskatalog, SHM. Stockholm.

- 1986. Gürtel und Gürtelzubehör vom orientalischen Typ. In: Arwidsson, G. (ed.) Birka Il:2. Systematische Anaslysen der Gräberfunde. KVHAA:87-108. Stockholm.

Kliastornyj, C. G. 1979. Kazarskaja nadpis na amfore $\mathrm{z}$ gorodishcha Majaki. Sovetskaja Archeologija No 1. Moskva.

Kmosko, M. 1924-1925. Araber und Chasaren. In: Korösi-Csoma-Archivum I/4 \& I/5:280292 \& 356-368. Budapest.

Koestler, A. 1976. The Thirteenth Tribe. The Khazar Empire and its Heritage. London.

- 1992. Den trettonde stammen. Hallonquists Bokförlag.

Kokovcov, P. K. 1932. Jevrejsko-khazarskaja perepiska v X veke. Akademija Nauk SSSR. Leningrad.

Lászlo, G. 1972. L'Art des Nomades. Paris. - 1974. The Art of the Migration Period. London. Ljapushkin,I.I. 1958. Pamiatniki Saltovo-Majackoj 
kultury v bassejnie r. Dona. Trudy Volgo-Donskoj Archeologicheskoj Ekspedicji I. Materialy i Issledovanija 62:85-150. Moskva-Leningrad.

Lowmianski, H. 1957. Zagadnienie roli Normanów w genezie panstw slowianskich. Warszawa.

Ludwig, D. 1983. Chazaren. Lexikon des Mittelalters vol II:1783-1788. München.

Magomedov, M. G. 1975. Kostjanyje nakladki sedla iz Verchne-Tchirjurtovskogo mogilnika. Sovetskaja Archeologija 1975 nr 1:275-281. Moskva.

- 1985. Obrazovanije Kazarskogo kaganata. Moskva.

Mikheev, V. K. 1986. Podonje v sostave Khazarskogo kaganata. Kiev.

Minorsky, V. 1978. The Turks, Iran and the Caucasus in the Middle Ages III. A new book on the Khazars. London.

Novoseltsev, A.P. 1982. K voprosu ob odnom iz drevnejshikh titulov russkogo knjazia. Istorija SSSR 4. Moskva.

Olofsson, R.P. 1994. En judisk stat vid Kaspiska Havet. Dala-Demokraten. 19 sep 1994.

Pelliot, P. 1949. Notes sur l'histoire de la Horde d'Or. Oeuvres posthumes de Paul Pelliot vol 2. Paris.

Petrukhin, V. J. 1989. K probleme formirovanija "Russkoj zemli" v srednem Podneprovje. Drevnejshije gossudarstva na territorii SSSR. 1987. Moskva.

- 1993. Varjagi i chazary v istorji Rusi. Etnograficheskoje obozrenije No 3. Moskva.

- 1995. The Early History of Old Russian Art: The Rython from Chernigov and Khazarian Tradition. Tor vol 27:2. Uppsala.

Pletnjeva, S. A. 1967. Ot kochevij k gorodam (Saltovo-Majackaja kultura). Materialy i $1 \mathrm{~s}$ sledovanija 142. Moskva-Leningrad.

- 1978. Die Chazaren. Leipzig.

- 1984. Risunki na stenach Majackogo gorodishcha. Majackoje gorodishche. Moskva.

- 1989. Na slaviano-kazarskom pogranichje. Dmitrijevskij archeologicheskij kompleks. Moskva.

Pletnjeva, S. A. et al. 1981. Archeologija SSSR. Stepi Eurasii $v$ epochu srednevekovja. Moskva.

Poliak, A. N. 1951. Khazariyah - The History of a Jewish Kingdom in Europe (in Hebr.). Tel Aviv.
Rispling, G. 1987. Coins with crosses and bird heads - Christian imitations of Islamic coins? Fornvännen 1987/2-3:75-87. Stockholm.

Rolle, R. 1981. Chazaren. In: Reallexikon der Germanischen Altertumskunde. B4:413-422. Berlin.

Rybakov, B. A. 1953. K voprosu o roli khazarskogo kaganata v istorii Rusi. Sovetskaja Archeologija 18:128-150. Moskva.

Shcherbak, A. M. 1959. Znaki na keramike i kirpichach iz Sarkela-Beloj Vezji. Trudy VolgoDonskoj Archeologicheskoj Ekspedicji II. Materialy i Issledovanija 75:362-389. MoskvaLeningrad.

Sharf, A. 1971. Byzantine Jewry - from Justinian to the Fourth Crusade. London.

Shennan, S. 1994. Introduction: archaeological approaches to cultural identity. In: S.J. Shennan (ed.) Archaeological Approches to Cultural Idenity. One World Archaeology 10. London \& New York.

Shnirelman, V. A. 1993. Zlokluchenija odnoj nauki: Etnogeneticheskije issledovanija i Stalinskaja nacjonalnaja politika. Etnograficheskoje obozrenije 3. Moskva.

Smilenko, A.T. 1965. Glodoski skarby. Kiev.

Smirnov, K. F. 1951. Aghachkalinskij mogilnik pamjatnik khazarskoj kultury Dagestana. Kratkije soobshchenija vol 38:113-119. Moskva-Leningrad.

Spicyn, A.A. 1909. Istoriko-archeologicheskije razyskanija. Iskonnyje obitateli Dona i Donca. Journal Ministerstva narodnogo prosveshchenija No 1. Moskva.

Svanberg, I. \& Runblom, H. 1991. Det mångkulturella Sverige. En handbok om etniska grupper och minoriteter. Stockholm.

Szyszman, S. 1957. Les Khazars. Problémes et Controverses. Revue de l'histoire des religions B $152 \mathrm{Nr}$ 2:174-221. Paris.

Togan, A. Z. Validi. 1940. Völkerschaften des Chazarenreiches im neunten Jahrhundert. Korösi Csoma-Archivum vol III/1:40-76. Budapest.

Tolstov, S. P. 1948. Po sledam drevnechorezmijskoj civilizacji. Moskva/Leningrad.

- 1953. Auf den Spuren der Altchoresmischen Kultur. Gesellschaft für Deutsch-Sowjetische Freund. Berlin.

Veit, U. 1994. Ethnic concepts in German prehistory: a case study on the relationship between cultural identity and archaeological objectivity, In: S.J. Shennan (ed.) Archaeological 
Approaches to Cultural Identity. One World Archaeology 10. London \& New York.

Werbart, B. 1994a. Complexity in the use of culture concepts. Current Swedish Archaeology vol 2. Stockholm.

- 1994b. Kultur, folk eller keramik? Om panorientalister, kossinister och anti-kossinister. Fördomar om etnicitet i arkeologi. In: Iregren, E. \& Werbart, B. (eds). Arkeologi och etik. University of Lund, Institute of Archaeology, Report series No 52. Lund.

- 1996 (in print). Archaeology and two-ways concepts of ethnicity. In: Funari, B., Hall, M. \& Jones, S. (eds.). Back from the Edge: Archaeology in History. One World Archaeology.
Southampton.

Wyszomirska, B. 1989. Religion som enande politisk-social länk - exempel: det kazariska riket. In: Larsson, L. \& Wyszomirska, B. (eds.) Arkeologi och Religion. University of Lund, Institute of Archaeology, Report Series 34: 135-148. Lund.

Zambaur, von E. 1902. Orientalische Münzen in Nord- und Osteuropa. Monatsblatt der Numismatischen Gesellschaft in Wien V:367-378. Wien.

- 1911. Die Münzen der Chasaren. Monatsblatt der Numismatischen Gesellschaft in Wien VIII: 313-315. Wien. 
